\title{
MICROBIAL AND SOIL PROPERTIES IN RESTORATION AREAS IN THE JEQUITINHONHA VALLEY, MINAS GERAIS ${ }^{(1)}$
}

\author{
Danielle Cristina Fonseca Santos ${ }^{(2)}$, Paulo Henrique Grazziotti ${ }^{(3)}$, \\ Alexandre Christófaro Silva ${ }^{(3)}$, Aldo Vilar Trindade ${ }^{(4)}$, Enilson de \\ Barros Silva ${ }^{(5)}$, Lidiomar Soares da Costa ${ }^{(6)}$ \& Hesmael Antônio \\ Orlandi $\operatorname{Costa}^{(7)}$
}

\begin{abstract}
To mitigate the impacts of eucalypt monoculture, forestry companies in the Upper Jequitinhonha Valley (MG) have adopted the insertion of strips of native vegetation in-between the commercial plantations. The method used for the creation of these corridors is to allow spontaneous regrowth of native vegetation in areas previously under eucalypt. The objective of this study was to evaluate the effect of cover crops on microbial and soil properties for a detailed description of the restoration process of native vegetation in forest soils of the Jequitinhonha Valley. The treatments were represented by an initial restoration stage $(<4$ years) with or without remaining eucalypt and the advanced restoration stage ( $>4$ years) with or without remaining eucalypt, plus the three controls: commercial eucalypt plantation, Cerrado vegetation and native forest. Soil samples were collected for three consecutive years in the dry and rainy season (August and February, respectively). The microbial activity, regardless of the presence of remaining eucalypt, did not differ among the restoration areas, except for the metabolic quotient $\left(\mathrm{qCO}_{2}\right)$ in the rainy season of February 2007. At this time, this microbial activity was higher in the advanced restoration stage without eucalypt than initial restoration without eucalypt and advanced restoration with eucalypt. The
\end{abstract}

\footnotetext{
(1) Part of the dissertation of first author, presented to the Master's degree in Produção Vegetal of the Universidade Federal dos Vales do Jequitinhonha e Mucuri - UFVJM. Received for publication in September 28, 2010 and approved in September 27, 2011.

(2) Graduated in Agronomy. Master in Vegetable Production, UFVJM. Campus JK. Rodovia MGT 367 - Km 583, nº 5000 - Alto da Jacuba, CEP 39100-000 Diamantina (MG), Brazil. E-mail: daniagronomia@yahoo.com.br

(3) Professor. Department of Forestry, UFVJM. E-mail:grazziot@yahoo.com.br

(4) Research. Embrapa Mandioca e Fruticultura. E-mail: aldo@cnpmf.embrapa.br

(5) Professor. Department of Agronomy, UFVJM. E-mail: ebsilva@ufvjm.edu.br

(6) Graduate student in Forestry, UFVJM. E-mail: lidiomar.ef@bol.com.br

(7) Master in Vegetable Production, UFVJM. E-mail: hesmaelorlandi@yahoo.com.br
} 
restoration areas, in general, did not differ from the control: eucalypt plantation and Cerrado either. Compared to the forest, the levels of organic $\mathrm{C}$, microbial $\mathrm{C}$, basal respiration (Rbasal) and hydrolysis of fluorescein diacetate (FDA) in the restoration areas were, in general, lower and did not differ in $\mathrm{qCO}_{2}$ and microbial quotient (qMIC). In general, the soil quality was similar in the initial and advanced restoration stages. Most of the soil and microbial properties in the three years indicated that the restoration areas were most similar to the Cerrado. In the advanced restoration areas without eucalypt compared to Cerrado, the lower $R_{\text {basal }}$ in the $3^{\text {rd }}$ year and the lower FDA and qMIC and higher $\mathrm{qCO}_{2}$ in the $2^{\text {nd }}$ year indicated that the removal of the remaining eucalypt trees was unfavorable for restoration.

Index terms: spontaneous regrowth, soil quality, degraded areas, microbial biomass, microbial activity.

\title{
RESUMO: PROPRIEDADES MICROBIANAS E DO SOLO EM ÁREAS EM RESTAURAÇÃO NO VALE DO JEQUITINHONHA, MINAS GERAIS
}

\begin{abstract}
O setor florestal no Alto Vale do Jequitinhonha (MG) tem adotado a criação de faixas com vegetação nativa entre os seus plantios comerciais, com o objetivo de reduzir os impactos negativos do monocultivo. O método utilizado para criação dessas faixas tem sido a restauração espontânea da vegetação nativa em áreas anteriormente cultivadas com eucalipto. Oobjetivo deste trabalho foi avaliar o efeito de coberturas vegetais sobre propriedades microbianas do solo, para melhor caracterizar o processo de restauração da vegetação nativa em solos florestais do Vale do Jequitinhonha, MG. Os tratamentos foram: restauração inicial (<4 anos) com ou sem remanescentes de eucalipto; restauração avançada (> 4 anos) com ou sem remanescentes de eucalipto; e os controles: plantio comercial de eucalipto, vegetação nativa de Cerrado e de mata. As amostras de solo foram coletadas por três anos consecutivos, nos meses de agosto $e$ fevereiro, representando, respectivamente, o periodo de estiagem e o de chuvas. As áreas em restauração, independentemente da presença de eucalipto remanescentes, não diferiram quanto a atividade microbiana, exceto para quociente metabólico $\left(\mathrm{qCO}_{2}\right)$ em fevereiro de 2007 período chuvoso. Nessa época, a atividade microbiana foi maior na restauração avançada sem eucalipto do que na restauração inicial sem eucalipto e restauração avançada com eucalipto. As áreas em restauração, em geral, também não diferiram dos controles: plantio de eucalipto e Cerrado. Em relação ao controle mata, as áreas em restauração apresentaram, em geral, menores teores de $C$ orgânico, $C$ microbiano, respiração basal $\left(R_{\text {basal }}\right)$ e hidrólise do diacetato de fluoresceina (FDA), não diferindo quanto ao $\mathrm{qCO}_{2}$ e quociente microbiano (qMIC). Em geral, as restaurações iniciais e avançadas apresentaram qualidade do solo semelhante. A maioria das propriedades do solo e microbianas, nos três anos avaliados, indicou que as áreas em restauração mostraram maior semelhança com a área de Cerrado. Nas áreas em restauração avançada sem eucalipto, a menor $R_{\text {basal }}$ no ano 3 e a menor FDA e qMIC e maior $q \mathrm{CO}_{2}$ no ano 2, em relação ao Cerrado, indicaram que a remoção do eucalipto remanescente não promoveu a restauração.
\end{abstract}

Termos de indexação: revegetação espontânea, qualidade de solo, áreas degradadas, biomassa microbiana, atividade microbiana.

\section{INTRODUCTION}

Companies of the forest sector have been implementing new methods to reduce the negative impacts of monoculture, resulting in the insertion of areas with native vegetation in-between commercial plantations. In addition to the reduction of the impacts, these areas serve as ecological corridors, contributing to the maintenance of biodiversity and as seed pools for the revegetation of degraded or cultivated areas. The method used to create these areas in the Upper Jequitinhonha valley (MG) is the spontaneous regrowth of native vegetation in areas of previous eucalypt cultivation, where the presence of remaining eucalypt trees is common. Studies have demonstrated that spontaneous restoration is appropriate to regain the sustainability of previously cultivated areas (Behera \& Sahani, 2003; Nappo et al., 2004). 
In this way, vegetation can recover from disturbances if secondary forest is allowed to grow in open areas where plant species naturally replace each other while ecological conditions are improved. These changes go on, until a well-structured and stable community is established (Martins, 2001). As there is no information about spontaneous vegetation restoration on forest soil in the Upper Jequitinhonha valley, appropriate ecological indicators are required that reflect the disturbance degree in ecosystems and the stage of the restoration process. Moreover, the analysis of microbial and biochemical indicators of soil quality is needed to obtain relevant information about soil functions and their performance in nutrient recycling and storage.

Since microorganisms act direct or indirectly on organic matter decomposition and on promotion and maintenance of several soil properties, some characteristics of soil microbial communities have been used as ecological indicators of ecosystem disturbances and plant cover restoration (Gama-Rodrigues et al., 2008; Yusuf et al., 2009). Microbial biomass is considered one of the most sensitive and effective indicators because it is directly influenced by biotic and abiotic factors. However, it is sensitive to system changes (Gama-Rodrigues et al., 2005).

In former coal mining areas in India, the $\mathrm{C}$ and $\mathrm{N}$ contents in the microbial biomass effectively distinguished areas after 20 years of spontaneous soil restoration from natural forests; the microbial biomass of the restoration area was $50 \%$ lower than of the forest (Srivastava et al., 1989). In a restoring seasonal deciduous forest in China, $\mathrm{C}$ of microbial biomass increased during the ecological sequence as follows: soil without vegetation $<$ herbaceous vegetation $<$ shrub vegetation $<$ tree vegetation (Wei et al., 2008). The author concluded that microbial biomass $\mathrm{C}$ was one of the main soil quality properties in the spontaneous restoration process and that the quality was gradually approaching climax vegetation. These results confirm the efficiency of this indicator for soil quality evaluations.

Soil microbial and biochemical properties such as the metabolic quotient $\left(\mathrm{qCO}_{2}\right)$ (ratio basal respiration: microbial C) and microbial quotient (qMIC) (ratio microbial C: organic C) are also cited in the literature as efficient properties to evaluate soil quality. Lower $\mathrm{qCO}_{2}$ values indicate that the soil microbial biomass is more efficient in using $\mathrm{C}$ and energy (Wardle \& Ghani, 1995), which is more common in environments with lower levels of disturbance or stress. Organic matter quality is indicated by qMIC.

These microbial properties were applied in a study to evaluate the dissimilarity between plant cover and acacia, "sabiá", or between eucalypt and pasture or "capoeira", in which microbial proved more efficient in discriminating areas than microbial properties and these in turn more than chemical properties (GamaRodrigues et al., 2008).
So far, there is no information about the stage of spontaneous revegetation evolution in the Upper Jequitinhonha valley, Minas Gerais. The purpose of this study was to evaluate the effects of plant cover types on microbial and soil properties, for a better characterization of the vegetation restoration process on forest soils in the Jequitinhonha valley.

\section{MATERIAL AND METHODS}

\section{Study area}

This study was carried out in areas of the company ArcelorMittal Energética Jequitinhonha Ltda, located on plateaus ("chapadas") of the Upper Jequitinhonha valley, in Itamarandiba, Capelinha, Turmalina and Minas Novas. in the State of Minas Gerais. The area has a flat, slightly undulated relief and is traditionally used for forestry. Predominant soils are Red-Yellow Latosol and Red Latosol, both typical dystrophic and clayey (Ferreira et al., 2010). The regional climate is Aw (Köppen classification), i.e, tropical with dry winters; the mean annual rainfall was $1050 \mathrm{~mm}$ (2005-2008), lowest annual mean $672 \mathrm{~mm}$ in 2007 and highest $1250 \mathrm{~mm}$ in 2006 , recorded at the company's weather station. The rainiest period is observed from November to March and lowest rainfall from May to August.

The original biome in the experimental areas is Cerrado, with the exception of the native forest control area, bordered by seasonal semideciduous forest. Native forest or seasonal semideciduous forest was observed in areas with drained relief and higher moisture. In the restoration areas, the predominant Cerrado plant species were Banisteriopsis sp., Bowdichia virgilioides, Cabralea canjerana, Caryocar brasiliense, Chamaecrista sp., Dalbergia miscolobium, Enterolobium gummiferum, Eriotheca gracilipes, Heteropterys byrsonimifolia, Kielmeyera lathrophytum, Miconia pohliana, Mimosa gemullata, Mimosa pithecolobioides, Ocotea aciphylla, Piptocarpa sp., Pouteria ramiflora, and Stryphnodendron adstringens.

\section{Treatments and experimental design}

On the selected areas, four different restoration stages were studied: (1) initial restoration, after less than 4 years, with remaining eucalypt (T1); (2) initial restoration, similar to treatment 1 , without remaining eucalypt (T2); (3) advanced restoration, vegetation regrowth for more than four years, with remaining eucalypt (T3); (4) advanced restoration, vegetation similar to treatment 3 , without remaining eucalypt (T4); and controls: (5) native Cerrado vegetation; (6) native forest vegetation; (7) commercial eucalypt plantation.

The experiment was installed in a completely randomized design in a hierarchical classification, where treatments were represented by seven plant 
covers, with four replications and each experimental unit consisted of a $400 \mathrm{~m}^{2}$ plot.

\section{Experiment installation and conduction}

Treatment plots in restoration were marked in areas (width $200 \mathrm{~m}$ ) of spontaneous revegetation inbetween eucalypt plantations (width $2000 \mathrm{~m}$ ). The plot areas had been used for eucalypt cultivation before. The last eucalypt harvest in treatments of initial restoration had occurred in 2001. However, to establish treatments without remaining eucalypt, remaining eucalypt was cut and manually removed together with $20 \mathrm{~m}$ of border in January 2004, repeating cutting when necessary. All plots were marked in January 2004. On the plots in advanced restoration stage with remaining trees, eucalypt had last been harvested in 1998 and, for the treatment in advanced restoration without eucalypt, the remaining trees were mechanically removed in 1998. Control plots were marked in a commercial plantation of Eucalyptus urophylla, changed /replanted ? in 2000. Forest and Cerrado control plots were marked in undisturbed areas.

\section{Sampling}

Properties were evaluated in soil samples of two seasons (August-dry and February- rainy), in three consecutive years, as follows: first year - August/2005 and February/2006; second year - August/2006 and February/2007; and third year - August/2007 and February/2008.

Ten soil sub-samples were randomly collected from the $0-5 \mathrm{~cm}$ layer, packaged in plastic bags and transported in thermal boxes to the Soil Microbiology Laboratory of the UFVJM (Universidade Federal dos Vales do Jequitinhonha e Mucuri) in Diamantina, where they were sieved $(2 \mathrm{~mm})$ to remove organic residues and roots. Then sub-samples were stored at $4{ }^{\circ} \mathrm{C}$ until microbial analyses and the others taken to the UFVJM Soil Laboratory to determine physical and chemical properties (Table 1).

\section{Laboratory analysis}

Soil moisture and maximum water holding capacity (MWHC) were determined as proposed by Monteiro \& Frighetto (2000). Flurescein diacetate hydrolysis (FDA) by soil microorganisms was evaluated according to Embrapa (2000). Soil basal respiration $\left(\mathrm{R}_{\text {basal }}\right)$ was estimated based on $\mathrm{CO}_{2}$ released from four sub-samples (20 g) taken from each composite sample (moisture content $60 \%$ of MWHC). The samples were sealed in a $1 \mathrm{~L}$ pot with $10 \mathrm{~mL}$ of $0.3 \mathrm{~mol} \mathrm{~L}^{-1} \mathrm{KOH}$ and titrated after three days with $0.1 \mathrm{~mol} \mathrm{~L}^{-1} \mathrm{HCl}$ (Alef, 1995). Soil microbial biomass $\mathrm{C}\left(\mathrm{C}_{\text {mic }}\right)$ was determined by fumigation and incubation, as described by Jenkinson \& Powlson (1976).

From each soil sample, eight sub-samples (20 g) were incubated at $25{ }^{\circ} \mathrm{C}$ for 10 days in $15 \mathrm{~mL}$ of $0.3 \mathrm{~mol} \mathrm{~L}{ }^{-1} \mathrm{KOH}$. The other four were fumigated with $25 \mathrm{~mL}$ of alcohol-free chloroform for $24 \mathrm{~h}$ in vacuum desiccators. Then chloroform was extracted in three successive aspirations and the material incubated as described for the non-fumigated samples. After incubation, $0.3 \mathrm{~mol} \mathrm{~L}^{-1} \mathrm{KOH}$ was titrated, as described for $\mathrm{R}_{\text {basal }}$. The quantity of $\mathrm{C}_{\text {mic }}$ was determined by the difference between $\mathrm{CO}_{2}$ released from fumigated and non-fumigated samples, using the correction factor (Kc) of 0.45 (Joergensen, 1995).

The metabolic quotient $\left(\mathrm{qCO}_{2}\right)$ was determined by the ratio between $\mathrm{R}_{\text {basal }}$ and $\mathrm{C}_{\text {mic }}$ (Anderson \& Domsch,

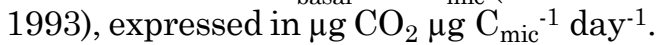

Soil organic $\mathrm{C}$ content $\left(\mathrm{C}_{\mathrm{org}}\right)$ was determined according to Walkley \& Black, (1944) and the microbial quotient (qMIC) calculated to determine the $\mathrm{C}_{\text {mic }}$ percentage of $\mathrm{C}_{\text {org }}$.

\section{Statistical analysis}

Annual results were submitted, separately, to variance analysis and means were compared by the Tukey test at $5 \%$.

Table 1. Means of pH values, available $\mathrm{P}, \mathrm{K}$, exchangeable $\mathrm{Al}$; and $\mathrm{Mg}, \mathrm{Ca}, \mathrm{H}+\mathrm{Al}$, sum of bases, effective $\mathrm{CEC}$, $\mathrm{CEC}$ at $\mathrm{pH}$ 7.0, Al saturation, soil base saturation in different restoration and management stages, and controls: eucalypt plantation, Cerrado and native forest in soil sampled from the $\mathbf{0}-\mathbf{5} \mathrm{cm}$ layer

\begin{tabular}{|c|c|c|c|c|c|c|c|c|c|c|c|c|c|c|c|}
\hline Vegetation & $\mathrm{pH}_{2} \mathrm{O}$ & $\mathbf{P}$ & $\mathbf{K}$ & $\mathrm{Ca}^{2+}$ & $\mathrm{Mg}^{2+}$ & $\mathrm{Al}^{3+}$ & $\mathrm{H}+\mathrm{Al}$ & SB & $\mathbf{t}$ & $\mathbf{T}$ & m & $\mathbf{V}$ & Sand & Clay & Silt \\
\hline & \multicolumn{3}{|c|}{$-\mathrm{mg} \mathrm{dm}^{-3}-$} & \multicolumn{7}{|c|}{$-\mathrm{cmol}_{\mathrm{c}} \mathrm{dm}^{-3}$} & \multicolumn{2}{|c|}{$-\%$} & \multicolumn{3}{|c|}{$-\mathrm{g} \mathrm{kg}^{-1}$} \\
\hline Eucalypt & 4.42 & 2.18 & 22.0 & 0.49 & 0.30 & 1.99 & 22.6 & 0.84 & 2.83 & 23.5 & 70.2 & 4.8 & 125 & 635 & 240 \\
\hline Initial restoration with remaining eucalypt (T1) & 4.49 & 1.28 & 22.3 & 0.33 & 0.23 & 1.55 & 20.5 & 0.62 & 2.17 & 21.1 & 71.5 & 3.6 & 161 & 623 & 217 \\
\hline Initial restoration without remaining eucalypt (T2) & 4.32 & 1.73 & 21.7 & 0.40 & 0.23 & 1.95 & 19.8 & 0.68 & 2.63 & 20.5 & 73.7 & 3.7 & 104 & 623 & 273 \\
\hline Advanced restoration with remaining eucalypt (T3) & 4.25 & 2.12 & 19.9 & 0.38 & 0.24 & 1.77 & 19.9 & 0.68 & 2.44 & 20.6 & 72.2 & 3.7 & 243 & 510 & 247 \\
\hline Advanced restoration without remaining eucalypt (T4) & 4.16 & 1.97 & 24.4 & 0.43 & 0.26 & 2.19 & 23.0 & 0.75 & 2.94 & 23.8 & 73.9 & 3.7 & 210 & 523 & 268 \\
\hline Cerrado & 4.36 & 1.19 & 21.6 & 0.35 & 0.22 & 1.90 & 19.7 & 0.63 & 2.53 & 20.3 & 74.7 & 3.4 & 283 & 485 & 232 \\
\hline Native forest vegetation & 4.26 & 1.31 & 22.7 & 0.44 & 0.28 & 1.96 & 19.7 & 0.78 & 2.74 & 20.5 & 68.5 & 5.0 & 283 & 535 & 182 \\
\hline
\end{tabular}

pH in water- ratio 1:2.5; $\mathrm{P}$ and $\mathrm{K}$ : Mehlich-1 Extractant; $\mathrm{Ca}^{2+}, \mathrm{Mg}^{2+}$ and $\mathrm{Al}^{3+}: \mathrm{KCl} 1 \mathrm{~mol} \mathrm{~L}{ }^{-1} \mathrm{Extractant}_{\mathrm{H}}+\mathrm{Al}$ : $\mathrm{Calcium}$ acetate $0.5 \mathrm{~mol} \mathrm{~L}{ }^{-1}$ Extractant ; Sand, Clay and Silt - pipette method (Embrapa, 1997); SB - Sum of bases; t: effective CEC ; T: CEC at $\mathrm{pH} 7.0$; m: Al saturation; V: base saturation. 


\section{RESULTS AND DISCUSSION}

In the years 1 and 2 , microbial activity measured by FDA was mainly influenced by the effects of sampling time (season) and plant cover type. In the third year, it was influenced only by sampling time (Table 2). However, soil microbial activity in the restoration areas did not differ between seasons and was only lower than in Cerrado (32\%) and forest (54\%) in the years 1 and 2 . These results indicate a recovery of this property in the studied areas, independent of remaining eucalypt.

Microbial activity measured by FDA was also similar in areas reforested with native and with exotic tree species such as Eucalyptus spp. (Silva et al., 2004), and in former bauxite mining areas, after one year of restoration, compared to the reference areas with tree vegetation (Carneiro et al., 2008).

$R_{\text {basal }}$ was influenced by the interaction between season and plant cover in the years 1 and 2 , and plant cover only in the third year $(p<0.05)$ (Table 2$)$. However, $\mathrm{R}_{\text {basal }}$ did not differ among restoration areas in any season or year. In the restoration areas $R_{\text {basal }}$ was equal to eucalypt control in all samples. However, in the first year, T1 and T4 areas, and in the second year T1 area, were not different from native forest, where $R_{\text {basal }}$ was higher. In the third year, higher $\mathrm{R}_{\text {basal }}$ was observed in Cerrado, with no difference from $\mathrm{T} 1$ and $\mathrm{T} 3$ areas. In the last year, soil $R_{\text {basal }}$ demonstrated that areas with remaining eucalypt are more similar to Cerrado and forest than the plots without remaining eucalypt.

In general, $R_{\text {basal }}$ was only influenced by season in the second year, being higher in the dry (August/2006) than in the rainy season (December/2006), contrary to results reported elsewhere (Behera \& Sahani, 2003; Gama-Rodrigues et al., 2005). Although sampling occurred in the dry season, it should be mentioned that the pluviometric mean $(156 \mathrm{~mm})$ from March to April 2006 (pre-sampling period) was higher than in the other years $(71 \mathrm{~mm}$ in 2005, $28 \mathrm{~mm}$ in 2007 and $88 \mathrm{~mm}$ in 2008), in other words, this higher precipitation could influence the microbial activity in the dry season of this year.

Higher rainfall may promote higher litter production, higher organic matter accumulation on the soil, and consequently, increase in microorganism activity (Gama-Rodrigues et al., 2005).

During the three years of sampling, $\mathrm{C}_{\text {mic }}$ in the restoration areas did not differ (Table 2). Higher contents were found in forest soil, and only in 2008, forest did not differ from Cerrado which in turn was equal to the other plant covers. These results indicate that the restoration areas are in a stage equivalent to Cerrado and eucalypt plantation, and that remaining eucalypt does not influence $\mathrm{C}_{\text {mic }}$.

In restoration areas after bauxite extraction, $\mathrm{C}_{\text {mic }}$ was similar to natural areas after one year (Carneiro et al., 2008). This may explain why these areas did not differ from Cerrado after restoration for at least four years. The natural vegetation in these areas was Cerrado, which may explain why the soil properties were more similar to Cerrado than to forest.

The similar $\mathrm{C}_{\text {mic }}$ contents in soils of eucalypt plantation, Cerrado and restoration areas may be explained by the higher plant biomass production, aside from fertilization, which also favors soil microbiota.

The higher $\mathrm{C}_{\text {mic }}$ in forest than in restoration areas may be because the forest areas in this study are seasonal semideciduous, i.e., a denser vegetation with higher plant biomass. Seasonal semideciduous forests are located in dissected areas, nearer to water tables and hydric sources where, in general, soil moisture is higher, favoring microbial activity. Other authors also observed higher $\mathrm{C}_{\text {mic }}$ contents in native areas that were not disturbed by pastures, annual crops (Oliveira et al., 2001) or eucalypt (Chaer \& Tótola, 2007).

In the first year, $\mathrm{qCO}_{2}$ was not influenced by the plant cover or seasons (Table 2). In the second year, in February with higher rainfall, $\mathrm{qCO}_{2}$ was higher in $\mathrm{T} 4$, not different from eucalypt plantation or T1 only.

In the third year, in spite of observing the effect of vegetation type by variance analysis, the test of means $(p<0.05)$ detected no differences among plant cover types, although the mean $\mathrm{qCO}_{2}$ in forest and eucalypt plantation (lower $\mathrm{qCO}_{2}$ ) was around half of the other areas and 2.4 times lower than in $\mathrm{T} 4$ (higher $\mathrm{qCO}_{2}$ ). These results indicate that despite the advanced restoration stage, the soil quality in $\mathrm{T} 4$ is poorer than in the others. Some authors concluded that the ecological stability is lower in areas with higher $\mathrm{qCO}_{2}$ (Chaer \& Tótola, 2007; Carneiro et al., 2008; GamaRodrigues et al., 2008).

A seasonal effect on $\mathrm{qCO}_{2}$ was only observed in the second year, being higher in the dry than the rainy seasons in T1, T2 and T3. This may explain the higher $R_{\text {basal }}$ observed in these areas also in the dry season of the same year (August 2006) (Table 2). The higher $\mathrm{qCO}_{2}$ indicated that the higher $\mathrm{R}_{\text {basal }}$ in these areas did not correspond exclusively to the higher microbial biomass but was rather caused by stress in this period.

$\mathrm{C}_{\text {org }}$ was influenced by season in the first two years and by plant cover type in all three. However, $\mathrm{C}_{\text {org }}$ in restoration areas did not differ from Cerrado and eucalypt soils. During the three years, $\mathrm{C}_{\text {org }}$ was higher in forest, except in the last year, when forest did not differ from eucalypt areas or T1. Results are similar to the ones observed for $\mathrm{C}_{\text {mic }}$ in the three years. Contents were higher in forest, while the other plant cover types did not differ from each other. Similar values of $\mathrm{C}$ in humic acid fractions, fulvic acids, light organic matter and microbial biomass of soil organic matter were also observed by Pulrolnik et al. (2009) in an eucalypt plantation in the Jequitinhonha valley and in Cerrado. 
Table 2. Soil microbial activity by flurescein diacetate hydrolysis (FDA), basal respiration $\left(\mathrm{R}_{\text {basal }}\right)$, microbial biomass $\mathrm{C}\left(\mathrm{C}_{\text {mic }}\right)$, metabolic quotient $\left(\mathrm{qCO}_{2}\right)$, organic $\mathrm{C}\left(\mathrm{C}_{\mathrm{org}}\right)$ and soil microbial quotient (qMIC) in three years, under different plant cover and restoration stages in the Upper Jequitinhonha valley, Minas Gerais

\begin{tabular}{|c|c|c|c|c|c|c|c|c|c|}
\hline \multirow{3}{*}{ Vegetation } & \multicolumn{9}{|c|}{ Time $^{(1)}$} \\
\hline & \multicolumn{3}{|c|}{ Year 1} & \multicolumn{3}{|c|}{ Year 2} & \multicolumn{3}{|c|}{ Year 3} \\
\hline & Aug/05 & Feb/06 & Means & Aug/06 & Feb/07 & Means & Aug/07 & Feb/08 & Means \\
\hline & \multicolumn{9}{|c|}{ FDA (mg kg $\left.{ }^{-1} \mathrm{~h}^{-1} \mathrm{FDA}\right)$} \\
\hline Eucalypt & 271 & 250 & $261 \mathrm{~b}$ & 231 & 292 & $261 \mathrm{bc}$ & 208 & 377 & 293 \\
\hline $\mathrm{T} 1$ & 278 & 250 & $264 \mathrm{~b}$ & 246 & 241 & $243 \mathrm{bc}$ & 219 & 417 & 318 \\
\hline $\mathrm{T} 2$ & 285 & 191 & $238 \mathrm{~b}$ & 187 & 331 & $259 \mathrm{bc}$ & 166 & 388 & 277 \\
\hline T3 & 322 & 280 & $301 \mathrm{~b}$ & 178 & 220 & $199 \mathrm{c}$ & 234 & 453 & 344 \\
\hline $\mathrm{T} 4$ & 241 & 273 & $257 \mathrm{~b}$ & 125 & 177 & $151 \mathrm{c}$ & 123 & 360 & 241 \\
\hline Cerrado & 409 & 287 & $348 \mathrm{~b}$ & 308 & 408 & $358 \mathrm{ab}$ & 269 & 321 & 295 \\
\hline Native forest & 619 & 470 & $544 \mathrm{a}$ & 469 & 519 & $494 \mathrm{a}$ & 399 & 383 & 391 \\
\hline \multirow[t]{2}{*}{ Means } & $346 \mathrm{~A}$ & $286 \mathrm{~B}$ & 316 & 249 B & $312 \mathrm{~A}$ & 281 & $231 \mathrm{~B}$ & $386 \mathrm{~A}$ & 308 \\
\hline & \multicolumn{9}{|c|}{$\mathrm{R}_{\text {basal }}\left(\mathrm{mg} \mathrm{kg}^{-1} \mathrm{~h}^{-1} \mathrm{CO}_{2}\right)$} \\
\hline Eucalypt & $2.60 \mathrm{Ab}$ & $3.08 \mathrm{Aa}$ & 2.84 & $4.80 \mathrm{Ab}$ & $2.16 \mathrm{Ba}$ & 3.48 & 3.83 & 1.47 & $2.65 \mathrm{~b}$ \\
\hline $\mathrm{T} 1$ & $3.43 \mathrm{Aab}$ & $4.09 \mathrm{Aa}$ & 3.76 & 6.60 Aab & $2.66 \mathrm{Ba}$ & 4.63 & 4. 79 & 4.32 & $4.55 \mathrm{ab}$ \\
\hline $\mathrm{T} 2$ & $4.86 \mathrm{Aab}$ & $3.51 \mathrm{Aa}$ & 4.19 & $5.72 \mathrm{Ab}$ & $0.36 \mathrm{Ba}$ & 3.04 & 4. 83 & 2.97 & $3.90 \mathrm{~b}$ \\
\hline $\mathrm{T} 3$ & $2.95 \mathrm{Ab}$ & $3.39 \mathrm{Aa}$ & 3.17 & $5.94 \mathrm{Ab}$ & $1.49 \mathrm{Ba}$ & 3.71 & 4.05 & 4.92 & $4.49 \mathrm{ab}$ \\
\hline $\mathrm{T} 4$ & $2.63 \mathrm{Bb}$ & $4.65 \mathrm{Aa}$ & 3.64 & $4.04 \mathrm{Ab}$ & $2.32 \mathrm{Aa}$ & 3.18 & 3.02 & 2.95 & $2.99 \mathrm{~b}$ \\
\hline Cerrado & $3.07 \mathrm{Ab}$ & $4.08 \mathrm{Aa}$ & 3.58 & $4.95 \mathrm{Ab}$ & $1.46 \mathrm{Ba}$ & 3.20 & 7.67 & 7.22 & $7.44 \mathrm{a}$ \\
\hline Native forest & $6.01 \mathrm{Aa}$ & $3.53 \mathrm{Ba}$ & 4.76 & $10.25 \mathrm{Aa}$ & $1.10 \mathrm{Ba}$ & 5.67 & 6. 18 & 5.04 & $5.61 \mathrm{ab}$ \\
\hline \multirow[t]{2}{*}{ Means } & 3.65 & 3.76 & 3.71 & 6.04 & 1.65 & 3.85 & 4. 91 & 4.13 & 4.52 \\
\hline & \multicolumn{9}{|c|}{$\mathrm{C}_{\text {mic }}\left(\mathrm{mg} \mathrm{kg}^{-1}\right.$ soil $)$} \\
\hline Eucalypt & 270 & 387 & $329 \mathrm{~b}$ & 264 & 196 & $230 \mathrm{~b}$ & 370 & 241 & $305 \mathrm{~b}$ \\
\hline $\mathrm{T} 1$ & 369 & 321 & $345 \mathrm{~b}$ & 204 & 208 & $206 \mathrm{~b}$ & 288 & 185 & $236 \mathrm{~b}$ \\
\hline $\mathrm{T} 2$ & 306 & 364 & $335 \mathrm{~b}$ & 266 & 211 & $238 \mathrm{~b}$ & 302 & 287 & $294 \mathrm{~b}$ \\
\hline T3 & 329 & 302 & $316 \mathrm{~b}$ & 220 & 195 & $207 \mathrm{~b}$ & 239 & 213 & $226 \mathrm{~b}$ \\
\hline $\mathrm{T} 4$ & 251 & 269 & $260 \mathrm{~b}$ & 225 & 94 & $159 \mathrm{~b}$ & 231 & 90 & $160 \mathrm{~b}$ \\
\hline Cerrado & 355 & 411 & $383 \mathrm{~b}$ & 333 & 289 & $311 \mathrm{~b}$ & 314 & 330 & $322 \mathrm{ab}$ \\
\hline Native forest & 743 & 704 & $724 \mathrm{a}$ & 655 & 374 & $515 \mathrm{a}$ & 602 & 459 & $531 \mathrm{a}$ \\
\hline \multirow[t]{2}{*}{ Means } & 375 & 394 & 384 & $309 \mathrm{~A}$ & $224 \mathrm{~B}$ & 267 & $335 \mathrm{~A}$ & $258 \mathrm{~B}$ & 296 \\
\hline & \multicolumn{9}{|c|}{$\mathrm{qCO}_{2}\left(\mu \mathrm{g} \mathrm{CO} \mathrm{CO}_{2} \mu \mathrm{g} \mathrm{C}_{\mathrm{mic}}^{-1} \mathrm{day}^{-1}\right)$} \\
\hline Eucalypt & 0.23 & 0.19 & 0.21 & $0.44 \mathrm{Aa}$ & $0.26 \mathrm{Aab}$ & 0.36 & 0.25 & 0.15 & $0.21 \mathrm{a}$ \\
\hline $\mathrm{T} 1$ & 0.22 & 0.31 & 0.26 & $0.78 \mathrm{Aa}$ & $0.31 \mathrm{Bab}$ & 0.54 & 0.40 & 0.56 & $0.46 \mathrm{a}$ \\
\hline $\mathrm{T} 2$ & 0.38 & 0.23 & 0.30 & $0.52 \mathrm{Aa}$ & $0.04 \mathrm{Bb}$ & 0.31 & 0.38 & 0.25 & $0.32 \mathrm{a}$ \\
\hline $\mathrm{T} 3$ & 0.22 & 0.27 & 0.24 & $0.65 \mathrm{Aa}$ & $0.18 \mathrm{Bb}$ & 0.43 & 0.41 & 0.55 & $0.48 \mathrm{a}$ \\
\hline $\mathrm{T} 4$ & 0.25 & 0.41 & 0.34 & $0.43 \mathrm{Ba}$ & $0.59 \mathrm{Aa}$ & 0.48 & 0.31 & 0.79 & $0.45 \mathrm{a}$ \\
\hline Cerrado & 0.21 & 0.24 & 0.22 & $0.36 \mathrm{Aa}$ & $0.12 \mathrm{Ab}$ & 0.25 & 0.59 & 0.53 & $0.55 \mathrm{a}$ \\
\hline Native forest & 0.19 & 0.12 & 0.16 & $0.38 \mathrm{Aa}$ & $0.07 \mathrm{Bb}$ & 0.26 & 0.25 & 0.26 & $0.25 \mathrm{a}$ \\
\hline \multirow[t]{2}{*}{ Means } & 0.23 & 0.23 & 0.23 & 0.47 & 0.18 & 0.35 & 0.35 & 0.38 & 0.37 \\
\hline & \multicolumn{9}{|c|}{$\mathrm{C}_{\text {org }}\left(\mathrm{g} \mathrm{kg}^{-1}\right.$ soil $)$} \\
\hline Eucalypt & 42 & 36 & $39 \mathrm{~b}$ & 37 & 33 & $35 \mathrm{~b}$ & 53 & 51 & $52 \mathrm{ab}$ \\
\hline $\mathrm{T} 1$ & 49 & 38 & $44 \mathrm{~b}$ & 40 & 25 & $32 \mathrm{~b}$ & 51 & 41 & $46 \mathrm{ab}$ \\
\hline $\mathrm{T} 2$ & 41 & 33 & $37 \mathrm{~b}$ & 39 & 25 & $32 \mathrm{~b}$ & 44 & 40 & $42 \mathrm{~b}$ \\
\hline $\mathrm{T} 3$ & 32 & 27 & $30 \mathrm{~b}$ & 37 & 22 & $30 \mathrm{~b}$ & 45 & 36 & $40 \mathrm{~b}$ \\
\hline $\mathrm{T} 4$ & 35 & 35 & $35 \mathrm{~b}$ & 35 & 30 & $33 \mathrm{~b}$ & 38 & 29 & $34 \mathrm{~b}$ \\
\hline Cerrado & 30 & 34 & $32 \mathrm{~b}$ & 30 & 29 & $29 \mathrm{~b}$ & 31 & 38 & $35 \mathrm{~b}$ \\
\hline Native forest & 66 & 56 & $61 \mathrm{a}$ & 65 & 51 & $58 \mathrm{a}$ & 79 & 64 & $71 \mathrm{a}$ \\
\hline \multirow[t]{2}{*}{ Means } & $42 \mathrm{~A}$ & $37 \mathrm{~B}$ & 39 & $41 \mathrm{~A}$ & $31 \mathrm{~B}$ & 36 & 49 & 43 & 46 \\
\hline & \multicolumn{9}{|c|}{ qMIC (\%) } \\
\hline Eucalypt & 0.64 & 1.08 & 0.84 & 0.71 & 0.59 & $0.66 \mathrm{ab}$ & 0.70 & 0.47 & 0.59 \\
\hline $\mathrm{T} 1$ & 0.75 & 0.84 & 0.78 & 0.51 & 0.83 & $0.64 \mathrm{ab}$ & 0.56 & 0.45 & 0.51 \\
\hline $\mathrm{T} 2$ & 0.75 & 1.10 & 0.91 & 0.68 & 0.84 & $0.74 \mathrm{ab}$ & 0.69 & 0.72 & 0.70 \\
\hline T3 & 1.03 & 1.12 & 1.05 & 0.59 & 0.89 & $0.69 \mathrm{ab}$ & 0.53 & 0.59 & 0.57 \\
\hline $\mathrm{T} 4$ & 0.72 & 0.77 & 0.74 & 0.64 & 0.31 & $0.48 \mathrm{~b}$ & 0.61 & 0.31 & 0.47 \\
\hline Cerrado & 1.18 & 1.21 & 1.20 & 1.11 & 1.00 & $1.07 \mathrm{a}$ & 1. 01 & 0.87 & 0.92 \\
\hline Native forest & 1.13 & 1.26 & 1.19 & 1.01 & 0.73 & $0.89 \mathrm{ab}$ & 0.76 & 0.72 & 0.75 \\
\hline Means & 0.89 & 1.06 & 0.98 & 0.75 & 0.72 & 0.74 & 0.68 & 0.60 & 0.64 \\
\hline
\end{tabular}

(1) Variables in which ANOVA was significant by the $\mathrm{F}$ test at $5 \%$; to same time, means followed by same letters are not different by Tukey's test at $5 \%$. Lower case letters compare means in columns. Capital letters compare means in rows T1: Initial restoration with eucalypt trees; T2: Initial restoration without remaining eucalypt; T3: Advanced restoration with eucalypt trees; T4: Advanced restoration without remaining eucalypt. 
Regarding seasons, in the first two years $\mathrm{C}_{\text {org }}$ was always higher in the dry seasons. This could be because of higher moisture some time before and consequently higher litter decomposition. These results, especially in the second year, may explain the higher $\mathrm{R}_{\text {basal }}$.

The plant cover type only influenced qMIC in the second year (Table 2), similar to $\mathrm{C}_{\text {org. }}$. The restoration areas did not differ from each other or from controls, including forest, except in T4, where qMIC was lower than in Cerrado soil. This result reinforces the data of other properties, showing a lower soil equilibrium in T4 with regard to soil microbial and biochemical properties. It indicates that the removal of remaining eucalypt trees affected results negatively.

The absence of significant differences in qMIC between Cerrado and T1, T2 and T3, indicates closeness to the ecological equilibrium in the vegetation restoration areas. The lack of difference between these areas and eucalypt monoculture could be explained by the fertilization of eucalypt and the fact that this plantation was seven years old.

In this study, qMIC values varied from 0.31 and $1.64 \%$ (Table 2), close to results reported by Chaer \& Tótola (2007) of soils under different eucalypt managements and native forest (0.81 to $1.54 \%$ ). However, these values were lower than in agricultural soils in temperate climate (2-7\%) (Anderson \& Domsch, 1989; Kandeler et al., 1993). These values in the Upper Jequitinhonha, and the differences to soils in areas of temperate climate, are most likely related to Latosol properties and predominant vegetation with lower plant biomass and lower density.

All microbial properties studied here and soil $\mathrm{C}_{\text {org }}$ indicated similarity of restoration areas with the Cerrado biome, except for FDA in the second year. In $\mathrm{T} 4, \mathrm{qCO}_{2}$ and $\mathrm{qMIC}$ indicate a less advanced restoration stage. This showed that, in general, remaining eucalypt trees favor restoration in these areas. The absence of any negative effect of the removal of remaining eucalypt in the initial restoration stage may be because of the shorter restoration time and the more recent harvest, which is a process involving the deposition of a great quantity of plant biomass on the soil.

\section{CONCLUSIONS}

1. The soil quality was similar in the initial and advanced restoration stages, except for $\mathrm{qCO}_{2}$ in the rainy season in the second year.

2. Most microbial and soil properties, during three years of evaluation, indicated similarity between restoration and Cerrado areas.

3. In advanced restoration areas without eucalypt, the lower $\mathrm{R}_{\text {basal }}$ in the third year, lower FDA and qMIC and higher $\mathrm{qCO}_{2}$ in the second year than in Cerrado soil indicated that the removal of remaining eucalypt trees did not promote restoration.

\section{ACKNOWLEDGEMENTS}

The authors are indebted to ArcelorMittal Energética Jequitinhonha Ltda for the financial support and scholarships and to the Brazilian Federal Agency for Support and Evaluation of Graduate Education (CAPES) for the scholarship of the first author.

\section{LITERATURE CITED}

ALEF, K. \& NANNIPIERI, P. Methods in applied soil microbiology and biochemistry. London, Academic Press, 1995. 576p.

ANDERSON, J.P.E. \& DOMSCH, K.H. The metabolic quotient $\left(\mathrm{qCO}_{2}\right)$ as a specific activity parameter to assess the effects of environmental conditions, such as $\mathrm{pH}$, on the microbial biomass of forest soils. Soil Biol. Biochem., 25:393-395, 1993.

ANDERSON, T.H. \& DOMSCH, K.H. Ratios of microbial biomass carbon to total organic carbon in arable soils. Soil Biol. Biochem., 21:471-479, 1989.

BEHERA, N. \& SAHANI, U. Soil microbial biomass and activity in response to Eucalyptus plantation and natural regeneration on tropical soil. Forest Ecol. Manag., 174:111, 2003.

CARNEIRO, M.A.C.; SIQUEIRA, J.O.; MOREIRA, F.M.S. \& SOARES, A.L.L. Carbono orgânico, nitrogênio total, biomassa e atividade microbiana do solo em duas cronossequências de reabilitação após a mineração de bauxita. R. Bras. Ci. Solo, 32:621-632, 2008.

CHAER, G.M. \& TÓTOLA, M.R. Impacto do manejo de resíduos orgânicos durante a reforma de plantios de eucalipto sobre indicadores de qualidade do solo. R. Bras. Ci. Solo, 3:13811396, 2007.

EMPRESA BRASILEIRA DE PESQUISA AGROPECUÁRIA . EMBRAPA. Indicadores biológicos e bioquímicos da qualidade do solo: Manual técnico. Rio de Janeiro, 2000. $198 \mathrm{p}$.

EMPRESA BRASILEIRA DE PESQUISA AGROPECUÁRIA EMBRAPA. Manual de métodos de análise de solo. 2.ed. Rio de Janeiro, 1997. 212p.

FERREIRA, C.A.; SILVA, A.C.; TORRADO, P.V. \& ROCHA, W. Genesis and classification of Oxisols in a highland toposequence of the upper Jequitinhonha Valley, MG. R. Bras. Ci. Solo, 34:195-210, 2010.

GAMA-RODRIGUES, E.F.; BARROS, N.F.; GAMARODRIGUES, A.C. \& SANTOS, G.A. Nitrogênio, carbono e atividade da biomassa microbiana do solo em plantações de eucalipto. R. Bras. Ci. Solo, 29:893-901, 2005. 
GAMA-RODRIGUES, E.F.; GAMA-RODRIGUES, A.C. \& FRANCO, A.A. Atributos químicos e microbianos de solos sob diferentes coberturas vegetais no norte do Estado do Rio de Janeiro. R. Bras. Ci. Solo, 32:1521-1530, 2008.

JENKINSON, D.S. \& POWLSON, D.S. The effects of biocidal treatments on metabolism in soil - V. A method for measuring soil biomass. Soil Biol. Biochem., 8:209-213, 1976.

JOERGENSEN, R.G. The fumigation incubation method. In: ALEF, K. \& NANNIPIERI, P. Methods in applied soil microbiology and biochemistry. London, Academic Press, 1995. p.376-381.

KANDELER， E.; MARGESIN，R.; ÖHLINGER，R. \& SCHINNER, F. Bodenmikrobiologisches MonitoringVorschläge für eine Bodenzustandsinventur. Die Bodenk., 44:357-377, 1993.

MARTINS, S.V. Recuperação de matas ciliares. Viçosa, MG, Aprenda Fácil, 2001. 143p.

MONTEIRO, R.T.R. \& FRIGHETTO, R.T.S. Determinação da umidade, $\mathrm{pH}$ e capacidade de retenção de água do solo. In: FRIGHETTO, R.T.S. \& VALARINI, P.J., Coord, Indicadores biológicos e bioquímicos da qualidade do solo: Manual técnico. Januária, Embrapa Meio Ambiente, 2000. 198 p.

NAPPO, M.E.; GRIFFITH, J.J.; MARTINS, S.V.; MARCOJÚNIOR, P.; SOUZA, A.L. \& OLIVEIRA-FILHO, A.T. Dinâmica da estrutura fitossociológica da regeneração natural em sub-bosque de Mimosa scabrella Bentham em área minerada, em poços de caldas, MG. R. Árvore, 28:811-829, 2004.

OLIVEIRA, J.R.A.; MENDES, L.C. \& VIVALDI, L. Carbono da biomassa microbiana em solos de Cerrado sob vegetação nativa e sob cultivo: Avaliação dos métodos de fumigação incubação e fumigação-extração. R. Bras. Ci. Solo, 25:863$871,2001$.
PULROLNIK, K.; BARROS, N.F.; SILVA, I.R.; NOVAIS, R.F. \& BRANDANI, C.B. Estoques de carbono e nitrogênio em frações lábeis e estáveis da matéria orgânica de solos sob eucalipto, pastagem e Cerrado no Vale do Jequitinhonha - MG. R. Bras. Ci. Solo, 33:1125-1136, 2009.

SILVA, M.; SIQUEIRA, E.R. \& COSTA, J.L.S. Hidrólise de diacetato de fluoresceína como bioindicador da atividade microbiológica de um solo submetido a reflorestamento. Ci. Rural, 34:1493-1496, 2004.

SRIVASTAVA, S.C.; JHA, A.K. \& SINGH, J.S. Changes with time in soil biomass $\mathrm{C}, \mathrm{N}$ and $\mathrm{P}$ of mine spoils in a dry tropical environment. Can. J. Soil Sci., 69:849-855, 1989.

WALKLEY, A. \& BLACK, I.A. An examination of the Degtjarref method for determining soil organic matter, and a proposed modification of the chromic acid titration method. Soil Sci., 37:29-38, 1934

WARDLE, D.A. \& GHANI, A. A critique of the microbial metabolic quotient $\left(q \mathrm{CO}_{2}\right)$ as a bioindicator of disturbance and ecosystem development. Soil Biol. Biochem., 27:16011610, 1995.

WEI,Y.; ZHANG, J. \& YU, L. Changes of soil microbial biomass carbon along successional processes of degraded Karst vegetation. Jornal of Nanjing Forestry University. 32: 5, $71-75,2008$.

YUSUF, A.A.; ABAIDOO, R.C.; IWUAFOR, E.N.O.; OLUFAJO, O.O. \& SANGINGA, N. Rotation effects of grain legumes and fallow on maize yield, microbial biomass and chemical properties of an Alfisol in the Nigerian savanna. Agri. Ecol. Environ., 129:325-331, 2009. 